\title{
A Survey of Environment and Demands Along with a Marketing Communications Plan for WatPutthabucha Market to Promote Agricultural Tourism through Main Media and Online Social Network Media
}

\author{
Kuntida Thamwipat \\ Department of Educational Communications and \\ Technology \\ Faculty of Industrial Education and Technology \\ King Mongkut's University of Technology Thonburi \\ Bangkok, Thailand
}

\author{
Nakorn Thamwipat \\ Wat Phothaimanee Buddhism School \\ Wat Phothaimanee \\ Phetchaburi, Thailand
}

\begin{abstract}
This study was aimed to examine the current environment and the demands and to make a marketing communications plan for WatPuttabucha Market to promote agricultural tourism through main media and online social network media. Moreover, it was aimed to build up working experiences for research with communities near the campus through the integration of course instruction and community service. The data were collected in the second term of academic year 2012 between January and February 2013 in WatPuttabucha Market and nearby communities. There were 2 sampling groups as in King Mongkut's University of Technology Thonburi students (50 persons) and WatPuttabucha Market and nearby community members (50 persons). In total, there were 100 persons for the survey. This collection was based on an accidental basis. According to the data concerning the environment, WatPuttabucha Market had 9 interesting shops for agricultural tourism and 4 major tourist attractions. As for the demands, it was found that 47 students (or 94\%) would like WatPuttabucha Market to be open as a site for agricultural tourism mainly on Saturday and Sunday. 47 persons from WatPuttabucha Market and nearby communities (or 94\%) also would like it to be open mainly on Saturday and Sunday. As for the communicative plan, it was found that there were 7 kinds of main media. There were 5 kinds of online social network media for check-in special events. The majority of students (mean score of 4.89 and standard deviation of 0.86 ) agreed with the integration of research in their Marketing Communication course because it allowed them to get more familiar with communities near the campus and recommended continuing this similar project for the next year.
\end{abstract}

Keywords-Environment; Marketing Communications Plan; Demands; Agricultural Tourism; Main Media; Online Social Network Media

\section{INTRODUCTION}

Department of Educational Communications and Technology, Faculty of Industrial Education and Technology, King Mongkut's University of Technology Thonburi initiated an ETM 358 Marketing Communications course [1] based on theories and practical fieldwork. In this course, students are expected to be able to apply theories and practical knowledge for their research to make a marketing communications plan through the integration of course instruction and community service within the area near the campus. Simultaneously, the representative from WatPuttabucha Market committee $\mathrm{Mr} \mathrm{Sa}$ ngiamNagasuthi, the host of E-Radio programme on agricultural tourism [2], asked for collaboration from the Department to use new kind of media, i.e. online social network media, along with main traditional existing media to promote agricultural tourism around WatPuttabucha Market. Hence, this research study on the survey of environment and demands as well as a marketing communications plan to promote agricultural tourism for WatPuttabucha Market and nearby communities.

\section{A. Research Objectives}

1) To examine the current environment and the demands as well as to make a marketing communications plan to promote agricultural tourism for WatPuttabucha Market and nearby communities through online social network media and traditional media.

2) To build up working experiences for research with communities near the campus through the integration of course instruction and community service.

\section{B. Expected Outcomes}

1) There would be data about the current environment and the demands as well as the marketing communications plan for WatPuttabucha Market to promote agricultural tourism through main media and online social network media.

2) Participants in this research would gain working experiences for research with the communities near the campus through the integration of course instruction and community service.

\section{Research Scope}

The data in this research were collected in the second term of the academic year 2012 between January and February 2013 in WatPuttabucha Market and nearby communities only. 


\section{POPUlATION AND SAMPLING GROUP}

To make a survey of the environment and the demands as well as a marketing communications plan, there were 2 sampling groups as in King Mongkut's University of Technology Thonburi students (50 persons) and WatPuttabucha Market and nearby community members (50 persons). In total, there were 100 persons and the data were collected on an accidental basis.

\section{VARIABLES IN THIS STUDY}

Below are the variables in this study:

A. The current environment of WatPuttabucha Market for agricultural tourism.

B. The demands on WatPuttabucha Market for agricultural tourism.

C. The marketing communications plan for WatPuttabucha Market for agricultural tourism through main media and online social network media.

\section{RESEARCH METHODOLOGY}

Below are the tools used in this research:

A. The data regarding the current environment of WatPuttabucha Market for agricultural tourism were collected through practical fieldwork for 2 months between January and February 2013 from WatPuttabucha Market and nearby communities.

B. The demands on WatPuttabucha Market for agricultural tourism were collected through a questionnaire.

C. The marketing communications plan for WatPuttabucha Market to promote agricultural tourism through main media and online social network media were collected through practical fieldwork and interviews with community leaders.

\section{RESEARCH RESUlTS}

A. The current environment of WatPuttabucha Market for agricultural tourism

1) Food and Dessert from 9 interesting shops.

a) Curry noodle: Location At the beginning of SoiPracha-Utit69, Pracha-Utit Road, Chef's dish:Meat curry noodle, Special flavour noodle, delicious curry soup, Price regular 20 Baht / special 30 Baht.

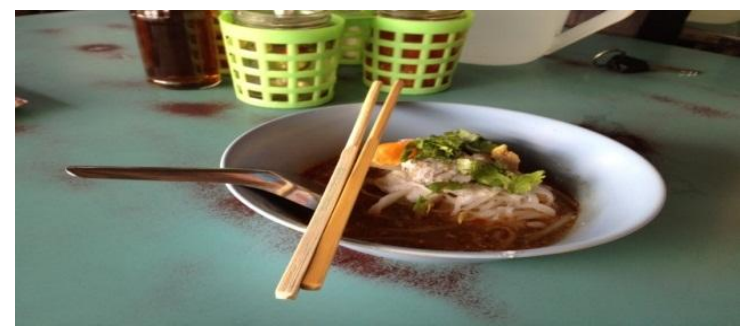

Fig. 1. Curry noodle. b) Pork Noodle by Sister Sa: Location In front of Lotus Pracha-Utit Department Store, Chef's dish: Pork noodle, Price: regular 15 Baht/Special 20 Baht/Takeaway 25 Baht.

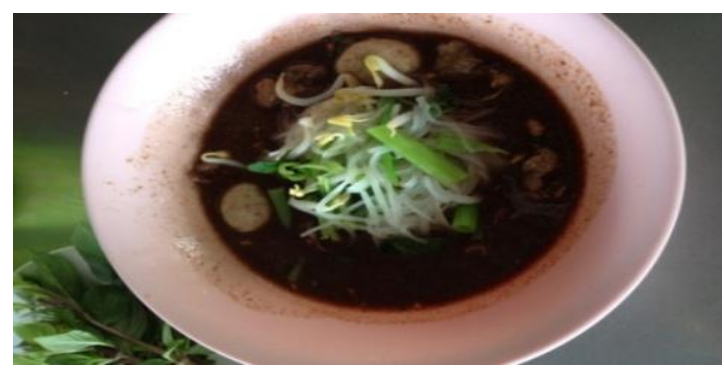

Fig. 2. Pork Noodle.

c) Wooden House Restaurant: Location SoiPuttabucha24 orRama II RoadSoi33, a few blocks from Rung-arun School, Chef's dish -Healthy food such as Mushroom salad, fried rice with gourami, grouper in chilli sauce, fried egg, fried rice with shrimp paste, tofu salad, Price 59-99 Baht.

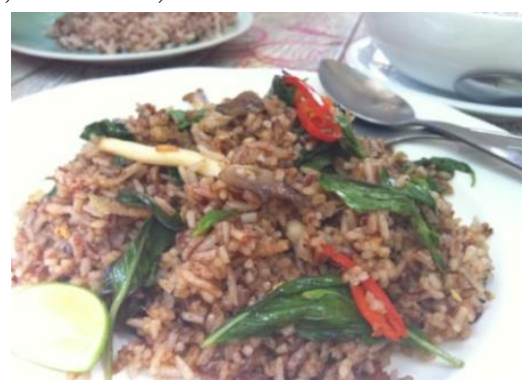

Fig. 3. Healthy food.

d) Seafood Restaurant (Sister Priaw): Location PrachaUtit91, Chef's dish:Crab meat fried rice and other kinds of seafood, Price from 40 Baht.

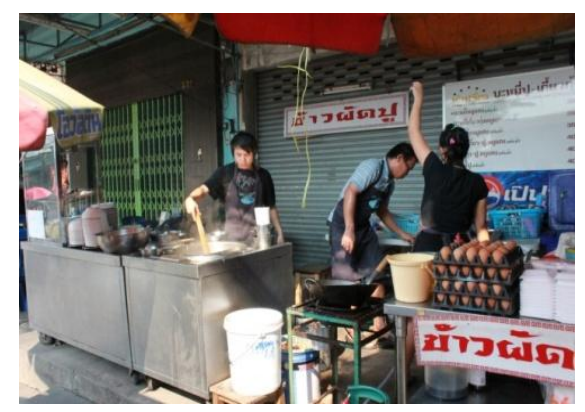

Fig. 4. Seafood Restaurant.

e) Bunnak Vietnamese Restaurant: Location Before PuttabuchaSoi 24, Chef's dish:Vietnamese sausage salad, Prawn in tiles, Vietnamese fried cake, pork rice ball, Price between 30-150 Baht.

f) Elephant's Neck Noodle Shop: Location SoiPuttabucha45, Chef's dish:Duck noodle, duck rice, pork satay, crunchy pork; Desserts include ladcheag, grilled sticky rice, Price regular noodle30 Baht/ special35 Baht/ with thigh 40 Baht. 


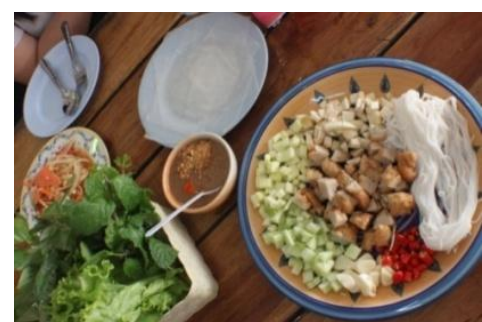

Fig. 5. Bunnak Vietnamese Restaurant.

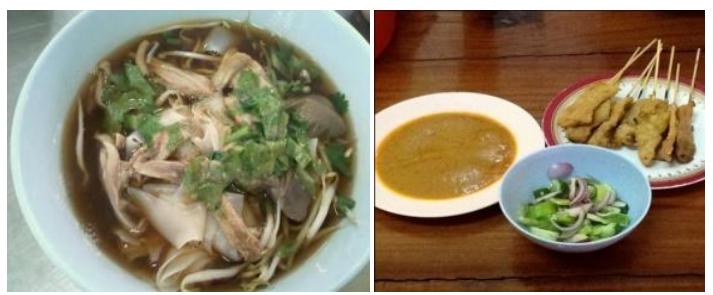

Fig. 6. Elephant's Neck Noodle Shop.

g) Duck Jelly Thanan: Location Pracha-Utit Soi54, Chef's dish:Duck jelly with fragrant coconut, Price small box of 14 pieces $30 \mathrm{Baht} / \mathrm{big}$ box of 42 pieces $80 \mathrm{Baht}$.

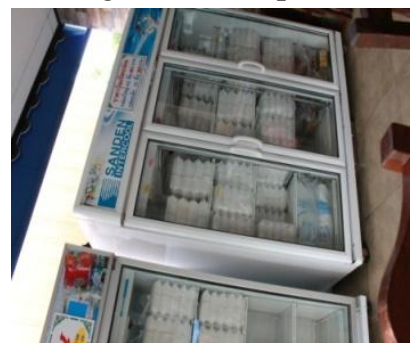

Fig. 7. Duck Jelly Thanan.

h) Dessert Shop Auntie Supaporn: Location Bangmod Housewife Community in SoiPuttabucha 36, Chef's dish:Pandan cake (Sukothai royal palace), filled bun, auspicious desserts (for wedding and merit occasions), Price Large tray of pandan cake350 Baht $/ 3$ bags of filled bun 10 Baht/ Egg threads 250 Baht per kilogramme.

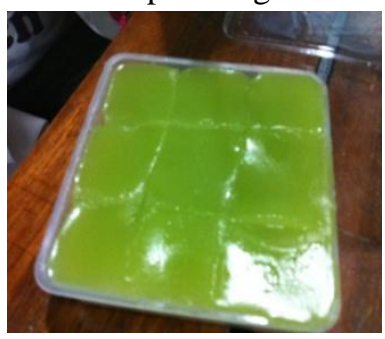

Fig. 8. Dessert Shop Auntie Supaporn.

i) Malabar tamarind Juice: Location Behind WatPuttabucha, near fish food shop at WatPuttabucha quayside, Recommended drink: malabar tamarind juice which could last for 2 months under the research by AjarnWannaphop Klomklieng, King Mongkut's University of Technology Thonburi, Priceone bottle13 Baht/150 Baht per kilogramme.

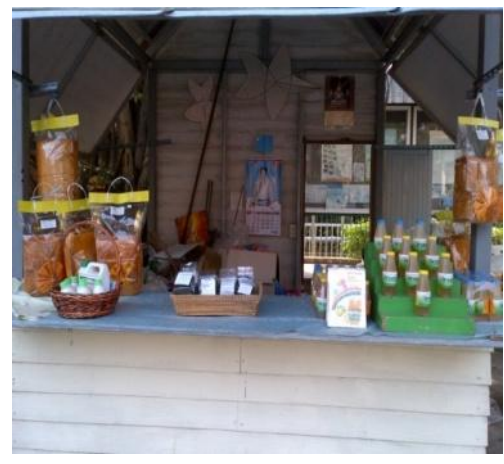

Fig. 9. Malabar Tamarind Juice.

\section{2) Major tourist attractions.}

a) Buddhism-Muslim Religious Centre: There are 3 old mosques: Darunnaeem, Al-Istikomah and Darul-Aeihsan (Sornsomboon).

b) Trail of 4 temples in Bangmod Area: WatBangmodSothararam, WatLuangPorOpasi, WatYairom and WatPuttabucha.

c) Community service around WatPuttabucha: Bangmod Massage Service Centre, Handmade Product by GovernmentSamaggi Housewife Group, Spots for freeing and feeding fish, Bangmod Cruise service.

d) Agricultural tourism spots: Mango garden of Uncle Praneet, Orchid garden of Auntie Saluay, Uncle Sawaeng, Orchid garden of Puttabucha, Orange orchard of Uncle Peed, Ideal orange orchard of Mr SupornWongjinda.

\section{B. The Demands on WatPuttabucha Market for Agricultural Tourism}

1) According to the survey on 50 King Mongkut's University of Technology Thonburi students,

It was found that there were 31 men or $62 \%$ and 19 women or $38 \%$. The majority was in their first year (29 persons or $58 \%$ ). It was found that the majority of the sampling group (28 persons or 56\%) had never been to WatPuttabucha Market. However, the majority (47 persons or $94 \%$ ) would like WatPuttabucha Market to be a site for agricultural tourism in Bangmod area.

The majority or $62 \%$ would like a retro style of market and this was followed by $22 \%$ of the sampling group who would like a floating market. The majority or $52 \%$ would like the market to be open mainly on Saturday and Sunday.

TABLE I. Shows THE BeHAVIOURS OF EXPOSURE To MAIN MEDIA

\begin{tabular}{|c|c|c|}
\hline Exposure to main media & $\begin{array}{c}\text { Number } \\
\text { persons }\end{array}$ & Percentage \\
\hline Printing materials & 32 & $34 \%$ \\
\hline TV programmes & 30 & $32 \%$ \\
\hline Radio programmes & 16 & $16.5 \%$ \\
\hline Open area broadcasting & 16 & $16.5 \%$ \\
\hline Others & 1 & $1 \%$ \\
\hline
\end{tabular}


TABLE II. SHOWS THE BEHAVIOURS OF EXPOSURE TO ONLINE SOCIAL NETWORK MEdia OR Alternative MEdia

\begin{tabular}{|c|c|c|}
\hline $\begin{array}{c}\text { Exposure to online social } \\
\text { network media and other } \\
\text { alternative media }\end{array}$ & $\begin{array}{c}\text { Number } \\
\text { persons }\end{array}$ & Percentage \\
\hline Internet & 39 & $53.42 \%$ \\
\hline $\begin{array}{c}\text { Online social network such as } \\
\text { facebook and twitter }\end{array}$ & 26 & $35.62 \%$ \\
\hline Community radio & 5 & $6.85 \%$ \\
\hline Others such as word of mouth & 3 & $4.1 \%$ \\
\hline
\end{tabular}

TABLE III. Shows THE DemandS ON SPECIAL ACtivities IN THE MARKET

\begin{tabular}{|c|c|c|}
\hline Opinion & $\begin{array}{c}\text { Number } \\
\text { persons }\end{array}$ & Percentage \\
\hline Food and product festivals & 30 & $50.85 \%$ \\
\hline Live bands & 12 & $27.12 \%$ \\
\hline Tourist attractions & 16 & $20.34 \%$ \\
\hline Others such as innovation & 1 & $1.69 \%$ \\
\hline
\end{tabular}

Further Suggestions: 1.It was expected that there would be more vegetable, fruit and organic food stalls than gift shop and clothes stall. and 2. This was a good project and it should be developed seriously.

2) According to the survey on 50 WatPuttabucha Market and nearby community members,

It was found that the sampling group consisted of 30 men $(60 \%)$ and 20 women (40\%). The majority were aged between $41-50$ years (15 persons or $30 \%$ ). The majority or $56 \%$ earned less than 15,000 Baht per month. The majority (47 persons or 94\%) would like WatPuttabucha Market to become a site for agricultural tourism and the majority or $42 \%$ would like it to be open mainly on Saturday and Sunday.

TABLE IV. SHOW THE BeHAVIOURS OF EXPosure to MaIN MEdiA

\begin{tabular}{|c|c|c|}
\hline Exposure to main media & $\begin{array}{c}\text { Number } \\
\text { persons }\end{array}$ & Percentage \\
\hline Printing materials & 20 & $20 \%$ \\
\hline TV programmes & 30 & $31 \%$ \\
\hline Radio programmes & 29 & $29 \%$ \\
\hline Open area broadcasting & 19 & $19 \%$ \\
\hline Others & 1 & $1 \%$ \\
\hline
\end{tabular}

TABLE V. SHOWS THE BeHAVIOURS OF EXPOSURE TO ONLINE SOCIAL NETWORK MEDIA OR ALTERNATIVE MEDIA

\begin{tabular}{|c|c|c|}
\hline $\begin{array}{c}\text { Exposure to online social } \\
\text { network media and other } \\
\text { alternative media }\end{array}$ & $\begin{array}{c}\text { Number } \\
\text { persons }\end{array}$ & Percentage \\
\hline Internet & 14 & $21 \%$ \\
\hline $\begin{array}{c}\text { Online social network such as } \\
\text { facebook and twitter }\end{array}$ & 8 & $12 \%$ \\
\hline Community radio & 37 & $56 \%$ \\
\hline Others such as word of mouth & 7 & $11 \%$ \\
\hline
\end{tabular}

TABLE VI. SHOWS THE DEMANDS ON SPECIAL ACTIVITIES IN THE MARKET

\begin{tabular}{|c|c|c|}
\hline Opinion & $\begin{array}{c}\text { Number } \\
\text { persons }\end{array}$ & Percentage \\
\hline Food and product festivals & 31 & $53.45 \%$ \\
\hline Live bands & 7 & $12.07 \%$ \\
\hline Tourist attractions & 16 & $27.59 \%$ \\
\hline Others such as innovation & 4 & $6.89 \%$ \\
\hline
\end{tabular}

Further Suggestions: 1.WatPuttabucha Market should be developed in terms of hygiene and order. and 2. If there is a development plan, it should be done seriously and in a concrete manner.

\section{The Marketing Communications Plan for WatPuttabucha to Promote Agricultural Tourism through Main Media and Online Social Network Media}

a) Main Media could be classified into 7 kinds as follows:

1) Production of TVC about Longka Market at WatPuttabucha (duration: 15 minutes).

2) Production of radioSpot about Longka Market at WatPuttabucha (duration: 30 seconds).

3) Production and Design of Mobile Advertisement.

4) Production and Design of Booklet about Longka Market at WatPuttabucha.

5) Production and Design of Leaflet about Longka Market at WatPuttabucha.

6) Production and Design of Vinyl to promote Longka Market at WatPuttabucha.

7) Production and Design of Brochure to promote Longka Market at WatPuttabucha.

\section{b) Samples of Main Media}

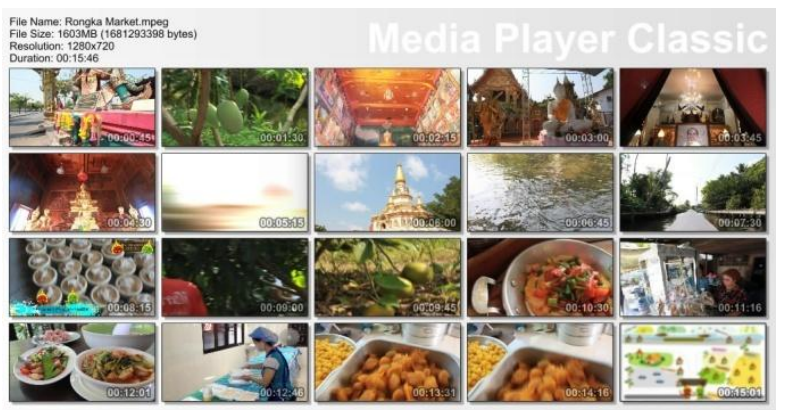

Fig. 10. TVC aboutL Longka Market at WatPuttabucha.

c) Details regarding Check-In (Event)/special activities through online social network and alternative mediacould be classified into 5 kinds:

- Planning Check-in activitieson various Social Media networks. When visitors arrive at Longka Market at WatPuttabucha, they could use their mobile phone to confirm their arrival and registration process to get a souvenir (a miniature of giant doll for modern-day mobile phone users). This was a virus-based marketing type which makes use of online social network to 
reduce the cost in accordance with the strategy called 'Above the Line'.

- Using Facebook to advertise main media such as TVC to invite visitors to come and to participate in the activities at the market.

- Using Facebook to announce the auspicious events such as paying homage to Buddha images, Buddhist Lent, Magha Puja Day, and Vesak.

- Using Facebook to announce other marketing promotion campaign for fruit season such as mango during the early year and orange during the end of the year.

- Organising a photo competition event about Rongka Market at WatPuttabucha on facebook.

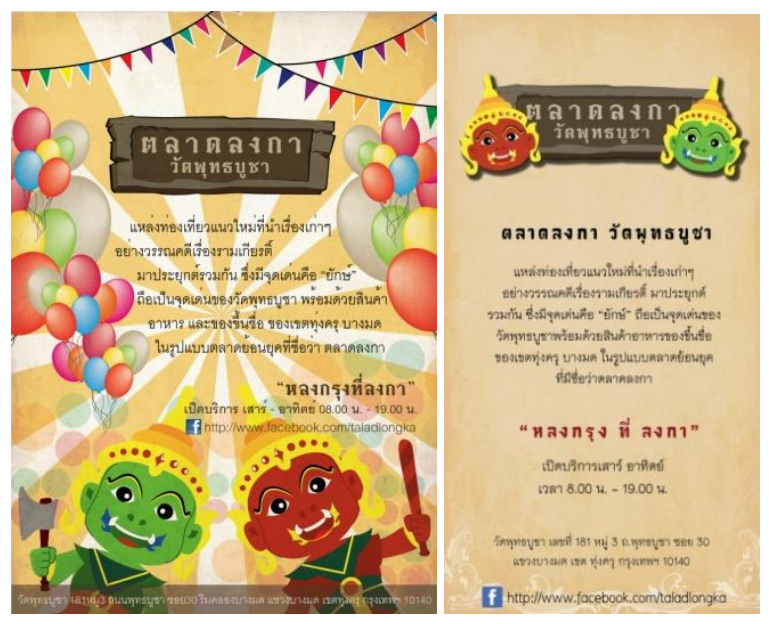

Fig. 11. Booklet.

d) Samples of online social network media and alternative media.
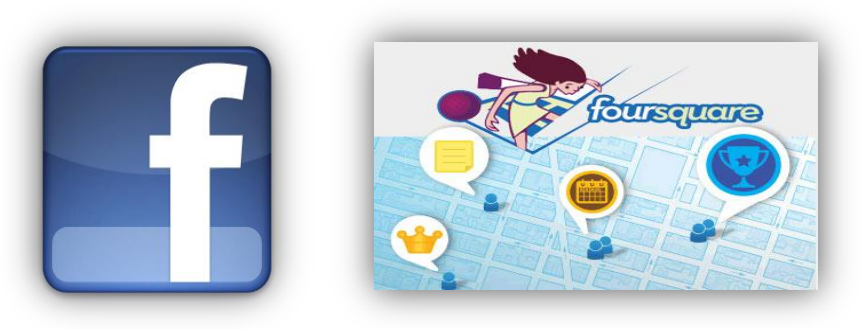

Fig. 12. Online Social Network Media.
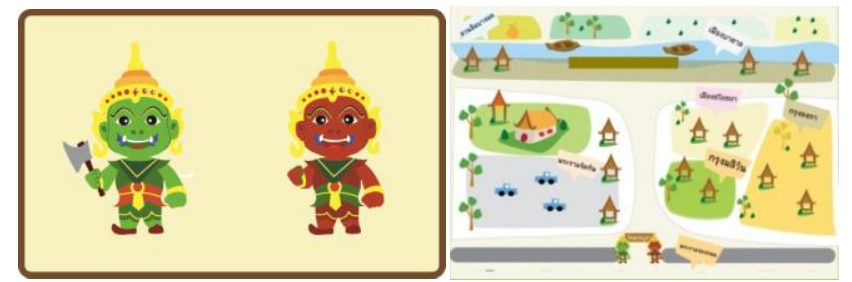

Fig. 13. Alternative Media. e) Result from the integration of community research in the Marketing Communications course.

The majority of the students (mean score of 4.89 and standard deviation of 0.86 ) strongly agreed with the integration of community research in the Marketing Communications course because it allowed them to get more familiar with the communities near the campus and they would like this project to continue in the next year. Moreover, the Department submitted a report about the survey results, demands and a marketing communications plan to the governmental organization in the community in March 2013.

\section{DISCUSSIONS}

According to the research study, it was found that the sampling group looked forward to the development of WatPuttabucha Market through the collaboration from many relevant organisations. Such policy was in compliance with the Green idea proposed by Jacquelyn A. Ottman cited in WeeraManaruaysombat [3] in that the world is changing and so is the expense behaviour of the housewives. Therefore, there must be a campaign to raise awareness of environment. Moreover, internet has improved dramatically and with its high speed of data distribution, internet has become an interactive medium for people to share information and discuss various issues ranging from agriculture, tourism and the like. Therefore, all relevant bodies should be aware of this trend.

\section{SUGgESTIONS}

\section{A. Suggestions from Research Results}

The research results show that both students and community members would like WatPuttabucha Market to become a site for agricultural tourism. Therefore, the relevant governmental sectors and the private organizations should collaborate to develop it intensely in the retro form or a floating market. Moreover, online social network should be considered along with main media for distribution of information.

\section{B. Suggestions for Further Research}

There should be a survey study on the environment and the demands of agricultural products through main media and online social network media in the communities behind Thonburi Rom Park and around King Mongkut's University of Technology Thonburi as a way to integrate it in the Marketing Communications course next year.

\section{REFERENCES}

[1] Department of Educational Communications and Technology, Faculty of Industrial Education and Technology, [Online], Avaiable: http://edt.kmutt.ac.th//ectmoodle, 2013, [Retrieved 10 February, 2013].

[2] Department of Educational Communications and Technology, Faculty of Industrial Education and Technology, [Online], Avaiable: http://202.44.14.12/e-broadcast/eradio.html, 2012, [Retrieved 8 February, 2013].

[3] Weera Manaruaysombat, 2011, Green Marketing: Blueprint for Globalized World. ARIP: Bangkok.1st Imprint, pp.32, 38-39. 